\title{
Genome-wide association study of morbid obesity in Han Chinese
}

\author{
Kuang-Mao Chiang ${ }^{1 \dagger}$, Heng-Cheng Chang ${ }^{2 \dagger}$, Hsin-Chou Yang ${ }^{3}$, Chien-Hsiun Chen ${ }^{1}$, Hsin-Hung Chen ${ }^{4}$, \\ Wei-Jei Lee $5^{5^{*}}$ and Wen-Harn Pan ${ }^{1,6^{*}}$ (i)
}

\begin{abstract}
Background: As obesity is becoming pandemic, morbid obesity (MO), an extreme type of obesity, is an emerging issue worldwide. It is imperative to understand the factors responsible for huge weight gain in certain populations in the modern society. Very few genome-wide association studies (GWAS) have been conducted on MO patients. This study is the first MO-GWAS study in the Han-Chinese population in Asia.

Methods: We conducted a two-stage GWAS with $1110 \mathrm{MO}$ bariatric patients (body mass index [BMI] $\geq 35 \mathrm{~kg} / \mathrm{m}^{2}$ ) from Min-Sheng General Hospital, Taiwan. The first stage involved 575 patients, and 1729 sex- and age-matched controls from the Taiwan Han Chinese Cell and Genome Bank. In the second stage, another 535 patients from the same hospital were genotyped for 52 single nucleotide polymorphisms (SNPs) discovered in the first stage, and 9145 matched controls from Taiwan Biobank were matched for confirmation analysis.

Results: The results of the joint analysis for the second stage revealed six top ranking SNPs, including rs8050136 ( $p$ value $\left.=7.80 \times 10^{-10}\right)$, rs9939609 $\left(p\right.$-value $\left.=1.32 \times 10^{-9}\right)$, rs1421085 $\left(p\right.$-value $\left.=1.54 \times 10^{-8}\right)$, rs9941349 $(p$-value $=$ $\left.9.05 \times 10^{-8}\right)$, rs1121980 $\left(p\right.$-value $\left.=7.27 \times 10^{-7}\right)$, and rs9937354 $\left(p\right.$-value $\left.=6.65 \times 10^{-7}\right)$, which were all located in FTO gene. Significant associations were also observed between MO and RBFOX1, RP11-638 L3.1, TMTC1, CBLN4, CSMD3, and ERBB4, respectively, using the Bonferroni correction criteria for 52 SNPs $\left(p<9.6 \times 10^{-4}\right)$.

Conclusion: The most significantly associated locus of $\mathrm{MO}$ in the Han-Chinese population was the well-known FTO gene. These SNPs located in intron 1, may include the leptin receptor modulator. Other significant loci, showing weak associations with $\mathrm{MO}$, also suggested the potential mechanism underlying the disorders with eating behaviors or brain/neural development.
\end{abstract}

Keywords: Morbid obesity, Body mass index, Genome-wide association study, FTO

\section{Background}

Obesity is a chronic phenomenon of positive energy balance, leading to the long-term and excessive accumulation of body fat. Epidemiological studies have revealed the substantial increase in the risk of NonCommunicable Diseases (NCD) in people with morbid obesity (MO) [1].

The latest evidence indicates the sharp rise in the prevalence of $\mathrm{MO}$ worldwide in both men and women

\footnotetext{
* Correspondence: wjlee_obessurg_tw@yahoo.com.tw;

pan@ibms.sinica.edu.tw

${ }^{+}$Kuang-Mao Chiang and Heng-Cheng Chang contributed equally to this work.

${ }^{5}$ Department of Surgery, Min-Sheng General Hospital, Taoyuan City, Taiwan ${ }^{1}$ Institute of Biomedical Sciences, Academia Sinica, Taipei City, Taiwan Full list of author information is available at the end of the article
}

[2]. In the US, the prevalence MO has increased by more than four-fold (1.4 to 6.3\%) within the last three decades [3]. Notably, the prevalence of MO (body mass index $\left.[\mathrm{BMI}] \geq 35 \mathrm{~kg} / \mathrm{m}^{2}\right)[4,5]$ in Taiwan has also increased from almost null to $1.3 \%$ during the past two decades, as per the data collected by the Nutrition and Health Survey in Taiwan (NAHSIT) from 1993 to 1996 to 20132016 [4]. As MO is accompanied with multiple comorbidity [6,7], including shorter life expectancy and higher all-cause mortality rate $[7,8]$ than that in general public, the associated medical cost and social economic burden are tremendous [9]. Lifestyle intervention measures are less efficient for MO cases, and bariatric surgery is expensive and could induce complications [10].

(c) The Author(s). 2019 Open Access This article is distributed under the terms of the Creative Commons Attribution 4.0 International License (http://creativecommons.org/licenses/by/4.0/), which permits unrestricted use, distribution, and reproduction in any medium, provided you give appropriate credit to the original author(s) and the source, provide a link to the Creative Commons license, and indicate if changes were made. The Creative Commons Public Domain Dedication waiver (http://creativecommons.org/publicdomain/zero/1.0/) applies to the data made available in this article, unless otherwise stated. 
The Global Burden of Disease study has pointed out poor diet (western or super-processed) in combination with physical inactivity/sedentary lifestyles as the main risk factors of non-communicable diseases, including obesity, diabetes [11-14], and associated cardio-metabolic diseases. However, BMI distribution is very wide, indicative of the differences in individual responses to the same obesogenic environment. It is worthy to investigate the genetic mechanisms underlying the development of extreme cases of obesity [15-18].

According to twin, family, and adoption studies, the heritability of BMI is estimated to be around $40-70 \%$ [19-22], and approximately $27 \%$ of BMI heritability may be attributed to common single nucleotide polymorphism (SNP) in adults [23]. A review on genome-wide association studies (GWAS) has documented at least 741 BMI- or obesity-related SNPs and numerous biological pathways [24]. MO, as the extreme type of obesity, may be highly associated with the common BMI-raising variants $[25,26]$.

Several GWAS have been performed on severe obesity and MO [27-33]. However, some of these MO-GWAS involved children or adolescents with high BMI percentile values, and all included European populations. Our study is the first MO-GWAS conducted in Chinese population in the Asian region.

\section{Results}

Additional file 1: Table S1 shows the comparison of the sample characteristics between MO patients at stage 1 and stage 2. No significant differences were observed between the two groups. Although some differences between the two control groups were noted, these differences (sex and age) were adjusted in the regression models.

\section{Two-stage GWAS}

Figure 1 is the Manhattan plots of the 1st stage MOGWAS. Additional file 1: Table S2 shows the 80 SNPs, with $p$-value $<10^{-4}$ considered for 2 nd stage confirmation. The SNP rs116917414 is the most significant SNP in the first stage GWAS ( $p$-value $=1.15 \times 10^{-12}$ ). Sixteen SNPs were not used for further analysis due to differences in probe design between CHB-1 Array and TWB Array. Twelve SNPs, which showed poor genotyping quality $(\mathrm{CR}<97 \%, \mathrm{MAF}<1 \%$, or $\mathrm{HWE}<0.001)$, were further removed. Finally, 52 SNPs were included in the 2nd stage. In the 2nd stage (Table 1), only one SNP, rs8050136 $\left(p\right.$-value $\left.=9.3 \times 10^{-4}\right)$, was significant following the Bonferroni correction $\left(p\right.$-value $<9.6 \times 10^{-4}$ $[0.05 / 52])$.

\section{Joint analyses}

Table 1 shows the results of the joint analyses for the 52 SNPs in $1110 \mathrm{MO}$ patients and 10,852 matched controls. Among these 52 SNPs, rs8050136 $\left(p\right.$-value $=7.80 \times 10^{-}$ $\left.{ }^{10}\right), \quad$ rs9939609 $\left(p\right.$-value $\left.=1.32 \times 10^{-9}\right), \quad$ rs1421085 $(p$ value $\left.=1.54 \times 10^{-8}\right), \quad$ rs9941349 $\left(p\right.$-value $\left.=9.05 \times 10^{-8}\right)$, rs1121980 $\left(p\right.$-value $\left.=7.27 \times 10^{-7}\right)$, and rs9937354 $(p$ value $=6.65 \times 10^{-7}$ ) were the top ranking SNPs, and all located in the same linkage disequilibrium (LD) block (Additional file 1: Figure S1) in the intron 1 of FTO gene. Nine additional SNPs showed statistical significance using the Bonferroni correction criteria ( $\mathrm{p}$-value $<$ $\left.9.6 \times 10^{-4}[0.05 / 52]\right)$. Seven SNPs flanked six loci as follows: RBFOX1 (rs12925846 [ $p$-value $=6.21 \times 10^{-6}$ ], and rs17235335 [ $p$-value $\left.\left.=1.26 \times 10^{-5}\right]\right), \quad R P 11-638 L 3.1$ $\left(\right.$ rs2126015, $p$-value $\left.=1.26 \times 10^{-5}\right)$, TMTC1 $($ rs159702, $p$ value $\left.=1.26 \times 10^{-5}\right), C B L N 4($ rs6069477, $p$-value $=1.26 \times$ $\left.10^{-5}\right), C S M D 3\left(\right.$ rs16883931, $p$-value $\left.=1.26 \times 10^{-5}\right)$, and ERBB4 (rs6757087, $p$-value $\left.=1.26 \times 10^{-5}\right)$. Two SNPs,

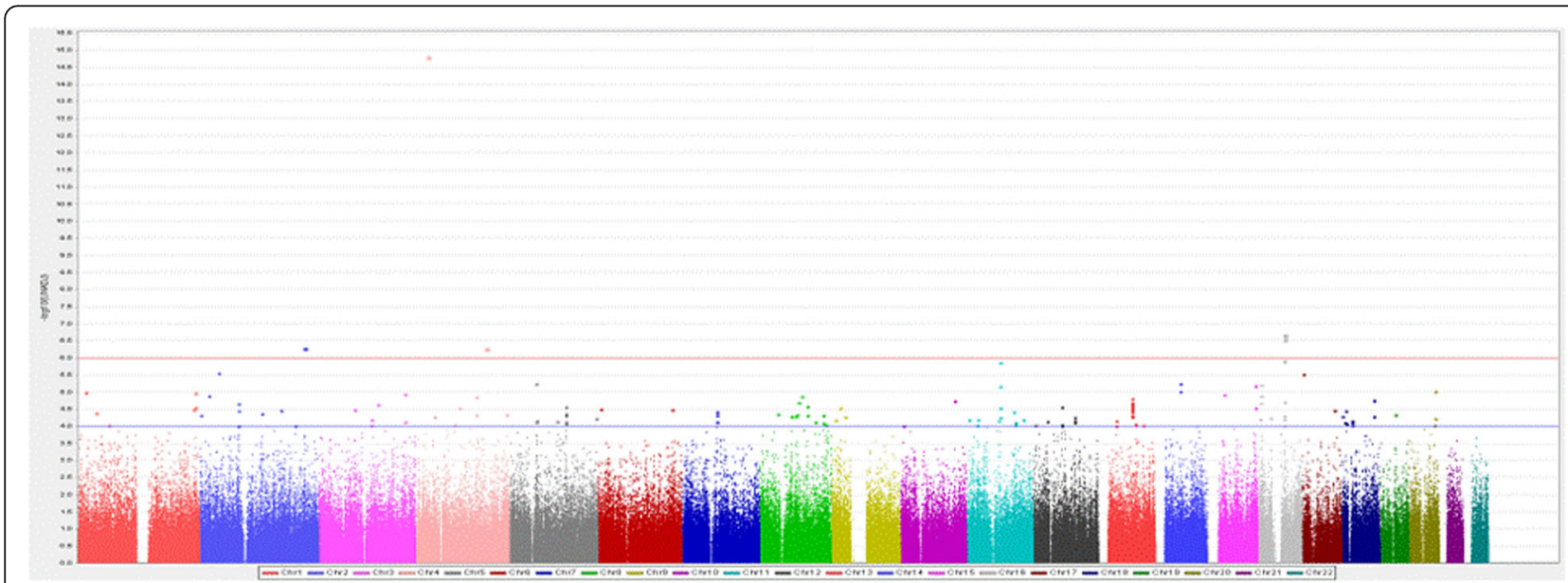

Fig. 1 The Manhattan plots of the first stage of MO-GWAS. GWAS for MO was analyzed by logistic regression with age, sex and PC 1 to PC10 adjustment. Blue line: $-\log 10$-value $=4$; Red line: $-\log 10$ p-value $=6$ 


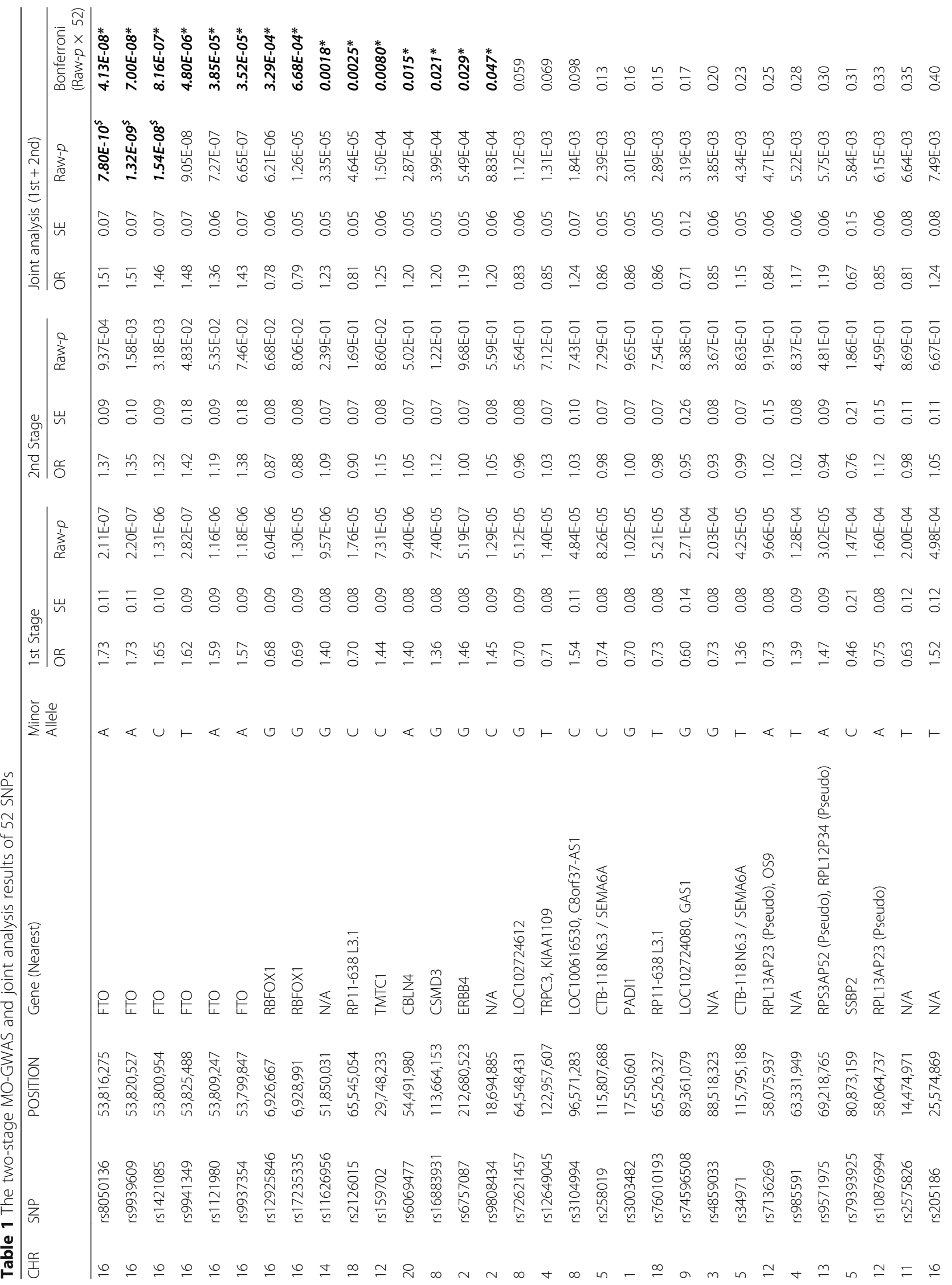




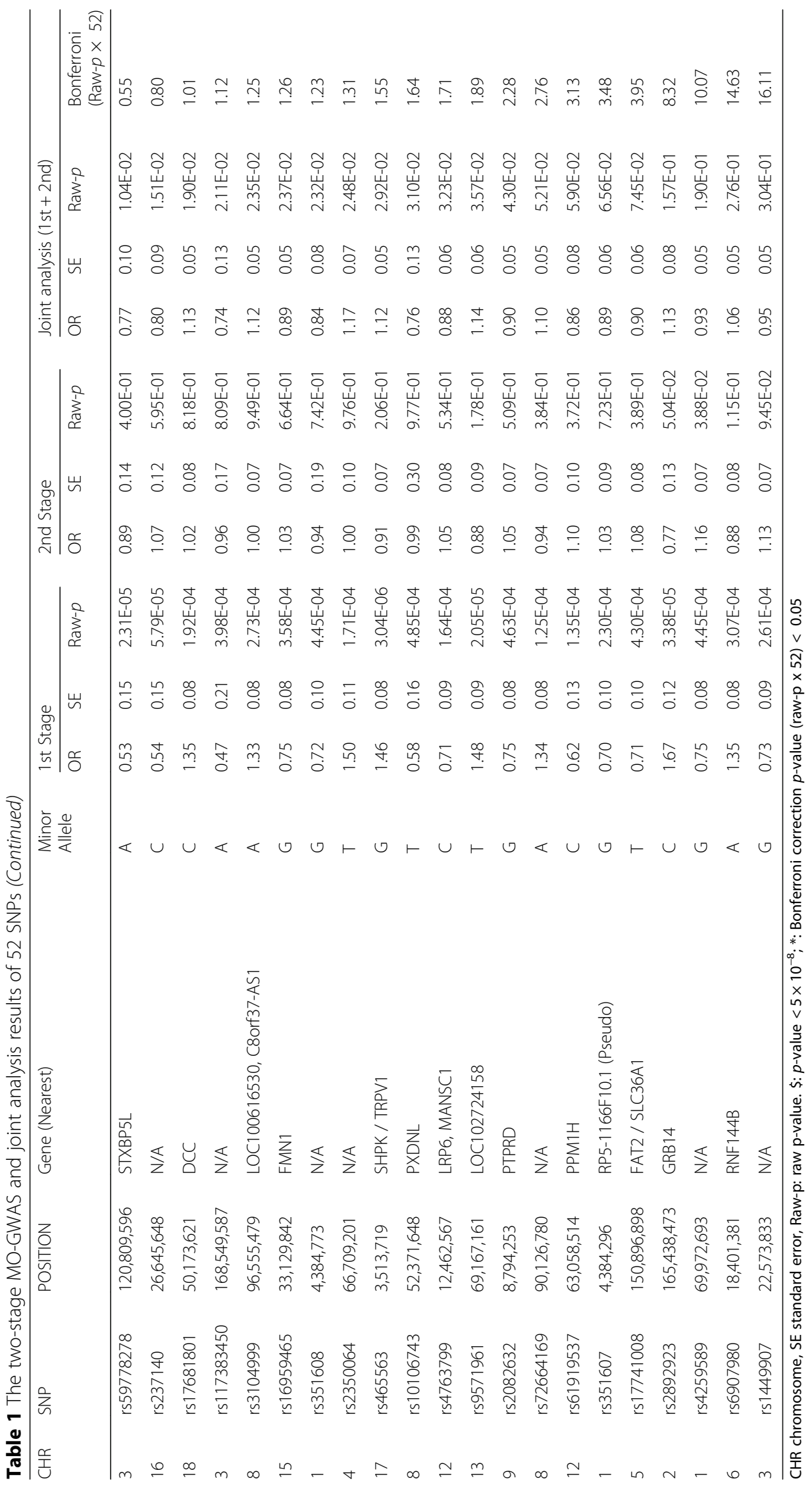


rs11626956 $\left(p\right.$-value $\left.=1.26 \times 10^{-5}\right)$, and rs9808434 $(p$ value $=1.26 \times 10^{-5}$ ) were located in an intergenic region.

\section{Discussion}

This is the first MO-GWAS conducted using the HanChinese population in Asia. This GWAS, with $1110 \mathrm{MO}$ patients and 10,852 matched controls in Han-Chinese population, established that the top 6 SNPs (rs8050136, rs9939609, rs1421085, rs9941349, rs1121980, and rs9937354) were all located in the most replicable obesity gene: the FTO.

In 2007, the well-known obesity gene, FTO, was first identified in a European ancestry population [34]. Since then, FTO has been replicated and validated in many other ethnic populations, including African [35] and Asian [36] populations. The association between FTO and severe obesity or MO is also reported in the European [37] and Japanese [38] populations. However, the evidence has been very limited for Han-Chinese, the largest population in the world.

In this two-stage GWAS, we found that six SNPs on FTO top all SNPs in association with morbid obesity in Han-Chinese (rs8050136, rs9939609, rs1421085, rs9941349, rs1121980, and rs9937354), especially with the rs8050136 and rs9939609 and rs1421085 reaching $p \leq 5 \times 10^{-8}$. According to our data and HapMap data, these six SNPs are within the same LD block in the intron 1 of FTO gene (Additional file 1: Figure S1). Of these, rs 9941349 was found to be associated with obesity for the first time.

The latest evidence indicated the association between rs9939609 of FTO $(p=0.026)$ and obesity $(\mathrm{BMI} \geq 30 \mathrm{~kg} /$ $\mathrm{m}^{2}$ ) in 1188 Taiwanese subjects [39]. A previous metaanalysis study with 4189 Han-Chinese individuals also validated the association between obesity (BMI $\geq 28 \mathrm{~kg} /$ $\mathrm{m}^{2}$ ) and rs9939609 (odds ratio [OR]: 1.39, $p$-value $=$ 0.02 ) along with rs8050136 (OR: 1.45, p-value $=0.01$ ) [40]. In addition, the association between rs8050136 and obesity (BMI $\geq 27.5 \mathrm{~kg} / \mathrm{m}^{2}$ ) is implicated in 1170 Chinese subjects [41], and rs1121980 has been replicated in HanChinese [42] and Malay populations [43]. Furthermore, rs1421085 is detectable in Chinese children aged 3 to 6 years [44].

Although rs9939609 is the most replicable FTO SNP, it is more prevalent in the European [45] populations (42\%), than in Africans (12\%) [46], East Asians (1220\%), and South Asians (30-33\%) [39]. In our study, the MAF of rs9939609 was only $13.2 \%$.

Claussnitzer et al. [47] suggested that rs1421085 may be the causal variant, instead of rs9939609 on FTO gene, as a single nucleotide variant alteration in rs1421085 (Tto-C) may cause disruption from the ARID5B-mediated suppression of IRX3 and IRX5, leading to adipocyte developmental shift from browning (energy expenditure) to whitening (energy storage), and suppression of mitochondrial thermogenesis.

The SNPs rs8050136, rs9937354, rs1421085, and rs1121980, in the first intron of FTO, are located in an enhancer region. Recent studies have indicated that the links between the intronic variance within FTO and body composition are mediated through functional interactions with neighboring genes. The first intron of FTO carries a binding site for the transcription factor CUX1, which modulates the leptin receptor localization within neurons, through the regulation of RPGRIP1L expression. This intron also contains an enhancer sequence that directly binds to the promoter of IRX3 [48, 49]. Therefore, the mechanisms underlying the contribution of FTO to the risk of obesity are apparently more complex than expected.

Aside from the FTO-related SNPs, nine SNPs were statistically significant according to the Bonferroni correction criteria, with $p$-value $<9.6 \times 10^{-4}(0.05 / 52)$ in the joint analysis. These SNPs flank RBFOX1, RP11-638 L3.1, TMTC1, CBLN4, CSMD3 and ERBB4 genes.

Two significant SNPs of RBFOX1 gene (RNA-binding fox-1 homolog 1) were discovered in this study, rs12925846 and rs17235335. This gene has been associated with several complex diseases, including schizophrenia, autism, mental retardation in epilepsy, attention deficit disorder, and obesity [50]. RBFOX1 is thought to affect adiposity through the hypothalamic melanocortin 4 receptor $(M C 4 R)$ pathway [51]. Mutations of $M C 4 R$ are known to cause a monogenic form of obesity in humans [52] via leptin. In the brain, the hypothalamus is known as the control center for satiety/hunger and social defeat. RBFOX1 gene, also known as ataxin-2binding protein 1 gene $(A 2 B P 1)$, could regulate neuronspecific splicing by binding to the pentanucleotide $(\mathrm{U})$ GCAUG sequences upstream of the regulated exon [53]. The involvement of RBFOX1 in obesity development is questionable and warrants further investigation.

One MO-associated SNP, rs2126015, is located on the RP11-638 L3.1 gene, a long noncoding RNA. Previous studies indicated the association of this SNP with neurological disorders such as attention deficit hyperactivity disorder (ADHD), and early-onset recurrent major depressive disorder (MDD) [54]. This gene is also highly expressed in the adipose tissue. IncRNAs are known to play important epigenetic regulatory roles in some important molecular processes, such as gene expression, genetic imprinting, histone modification, chromatin dynamics, and other activities, including formation of specific structures and interactions with all kinds of molecules [55]. The involvement of epigenetic modifications in the development of obesity is becoming increasingly evident [56, 57]. Obesity is associated with environmental pollutants (obesogens) [58], gut 
microbiota [59], and unbalanced food intake, all of which may result in weight gain, and altered metabolic consequences through epigenetic mechanisms. Further studies with a larger sample size are warranted to examine the interactions between genes and environmental factors, particularly dietary factors.

The gene TMTC1 (rs159702) has been associated with heart failure in an African ancestry population [60]. Moreover, the interaction of TMTC1 with abdominal obesity may contribute to phenotypic variation of left ventricular mass (LVM) [61]. However, the mechanism of TMTC1 involvement in MO remains unclear.

The proteins encoded by gene CBLN4 (rs6069477) are involved in the regulation of neurexin signaling during synapse development. Agouti related protein (AGRP)-expressing neurons are a key starvation-sensitive hypothalamic population, activated during energy deficit and increases appetite and weight gain. An animal study has shown that, CBLN4 is downregulated in AGRP neurons after food-deprivation [62]. It is worth further investigating the mechanism between this gene and $\mathrm{MO}$.

The rs16883931 is located in the CSMD3 (CUB and Sushi Multiple Domains 3). This gene is a large protein expressed in the fetal and adult brain and is involved in dendrite development. Mutations of the CSMD3 gene were identified in schizophrenic and autistic patients. However, biochemical properties and functions of the CSMD3 protein remain unknown [63].

Another MO-associated gene ERBB4 (rs29944391) is a member of the EGF receptor family. Genetic studies have indicated a link between ERBB4 and type 2 diabetes, and obesity. Neuroregulin 4 (NRG4), a ligand that specifically binds to $E R B B 4$, has been reported to promote browning of white fat, fuel oxidation, prevention of high-fat diet-induced obesity, and improvement of insulin sensitivity [64].

The SNP rs116917414 was the most significant SNP in the first stage GWAS ( $p$-value $=1.15 \times 10^{-12}$ ). However, this SNP was not included in the second stage owing to the failure in probe design. While we searched for a proxy SNP for rs116917414 using 1000 Genome database, we were unable to detect any SNP in strong LD $\left(r^{2}>0.8\right)$ with rs116917414. Hence, we used the nextgeneration sequencing data $(N=1445)$ collected from the Taiwan Biobank to investigate the association between rs116917414 and BMI. No significant association was found between this $\mathrm{SNP}$ and BMI $\left(p_{\mathrm{GA}}\right.$ vs. GG $=0.6$, $p_{\text {AA vs. GG }}=0.5$ ) (Additional file 1: Table S4), indicating the necessity for a larger sample size to confirm its effects. This SNP resides in the conserved noncoding region close to the RP11-380P13.1 (ENSG00000250137) pseudogene promoter $5^{\prime}$-region. Notably, a study using Framingham data has reported the location of rs2130928 in the RP11-380P13.1 and its association with BMI ( $p=$
0.0012) [65]. As only little is known about the RP11380P13.1, it is worthy of further research.

A recent GWAS for BMI in the Japanese population identified 85 SNPs [66]. We have investigated the association of these SNPs in our Han-Chinese population. Only six of these SNPs could be replicated in our study population $(p<0.05)$ (Additional file 1: Table S3), probably owing to the differences in studied traits, designs, and populations, as one involves cross-sectional GWAS with BMI as a quantitative trait in the Japanese general population, and the other was a case-control GWAS study of Chinese MO.

As this is the first large-scale MO-GWAS performed in the Han-Chinese population, the biological mechanisms or pathways known for some of the discovered genes are limited. Validation and mechanistic studies of these discovered genes are crucial. Patients with $\mathrm{MO}$ are those at the extreme tail of BMI distribution in population, within the same obesogenic environment. These patients show much higher increase in mean BMI in obesogenic environments, owing to genetic susceptibility [15-18]. A recent thought on the genetic underspin of the common complex traits is that "genes load the gun, but the environment pulls the trigger [67]." There were no obese individuals during famines, and the prevalence of obesity increased with increase in food supply. The subjects that present with greater genetic susceptibility to obesity are likely to gain more weight or fat in obesogenic environments. Individuals that carry the risk allele of FTO gene tend to have a higher protein [68] and calorie [69] intake. The interaction between genetic risk scores (from known obesity-related variants), and total fried food consumption and physical activity has been reported in NHS, HPFS, and Women's Genome Health Study [70]. Moreover, the behavioral susceptibility theory has also suggested that genes control the response to food cues (smell, sight, and taste), and determine sensitivity to satiety in obesogenic environments [67].

\section{Conclusions}

In summary, this is the first study illustrating genetic characteristics of MO in the Han-Chinese population. The most significantly associated locus of MO, in HanChinese population, was the well-known FTO gene. These SNPs, located in the intron 1, may include the leptin receptor modulator. In addition, other significant loci, including RBFOX1, RP11-638 L3.1, TMTC1, $C B L N 4, C S M D 3$, and ERBB4, showing weak associations with $M O$, suggested the potential mechanism underlying disorders with altered eating behaviors or brain/neural development, warranting further study on satiety control. Our results highlight the complexity of genetic involvement in the development of MO in humans. 


\section{Methods}

\section{Study design and sample size}

We conducted a two-stage GWAS in Taiwan HanChinese population of 1110 patients with MO between 19 to 55 years of age. In total, 575 patients were included in the first stage and 535 patients, in the second stage. At the end, we carried out a joint analysis for those SNPs showing significant tendency in the first stage.

The study flow chart is provided in Fig. 2. MO cases, defined by $\mathrm{BMI} \geq 35 \mathrm{~kg} / \mathrm{m}^{2}[4,5]$, were recruited from the Minimally Invasive Surgery Center of Min-Sheng General Hospital, Taoyuan city, Taiwan. Patients diagnosed with psychosis, developmental diseases, and cancer were excluded. In western countries, $\mathrm{MO}$ is defined as $\mathrm{BMI} \geq 40$ $\mathrm{kg} / \mathrm{m}^{2}$. Bariatric surgery is an optional treatment for people with $\mathrm{MO}$ that meet the following criteria: $\mathrm{BMI} \geq$ $40 \mathrm{~kg} / \mathrm{m}^{2}$ or between 35 and $40 \mathrm{~kg} / \mathrm{m}^{2}$ and other significant diseases (for example type 2 diabetes or high blood pressure). However, it is generally accepted that the BMI cut-off points for defining obesity should be lower for Asians [71]. In 2011, the Asian Pacific Metabolic and Bariatric Surgery Society suggested that [5] bariatric surgery should be considered as a treatment option for obesity in people with Asian ethnicity when (1) BMI $>35 \mathrm{~kg} / \mathrm{m}^{2}$ with or without co-morbidities, or (2) BMI ranged from 32 to $35 \mathrm{~kg} / \mathrm{m}^{2}$ with co-morbidities. We used the definition of Asian Pacific Metabolic and Bariatric Surgery Society to recruit patients with $\mathrm{MO}$.
For the control groups. In the first discovery stage, 1707age ( \pm 3 years) and sex matched controls (BMI $<35$ $\mathrm{kg} / \mathrm{m}^{2}$ ) were included from Han-Chinese Cell and Genome Bank in Taiwan (HanBKT) established from October 1, 2002, to January 14, 2004. The recruitment procedure and data collection have been previously reported [72]. In brief, it aimed to collect representative genetic samples to document genetic diversity in Taiwan Han-Chinese and to serve as controls in disease association studies. In the second confirmatory stage, another independent set of 9145age ( \pm 5 years) and sex matched controls $\left(\mathrm{BMI}<35 \mathrm{~kg} / \mathrm{m}^{2}\right)$ was included from Taiwan Biobank (TWB) [73]. Details on the TWB can be found on its official website (https://taiwanview.twbiobank.org. tw/index). Altogether, 10,852 subjects (1110 MO cases and 9742matched controls) were included in the joint GWAS.

\section{DNA extraction and genotyping}

DNA from MO cases was extracted from buffy coats of whole blood using the phenol-chloroform method [74]. Genomic DNA of controls collected by HanBKT and TWB were isolated from leukocytes using Puregene DNA purification kit (Gentra Systems, Minneapolis, MN, USA) [72, 73, 75] and its quality was assessed from the ratio of absorbance recorded at 260 and $280 \mathrm{~nm}$ wavelengths using a NanoDrop ND-1000 spectrophotometer (NanoDrop Technologies, DE, USA) [72-75].

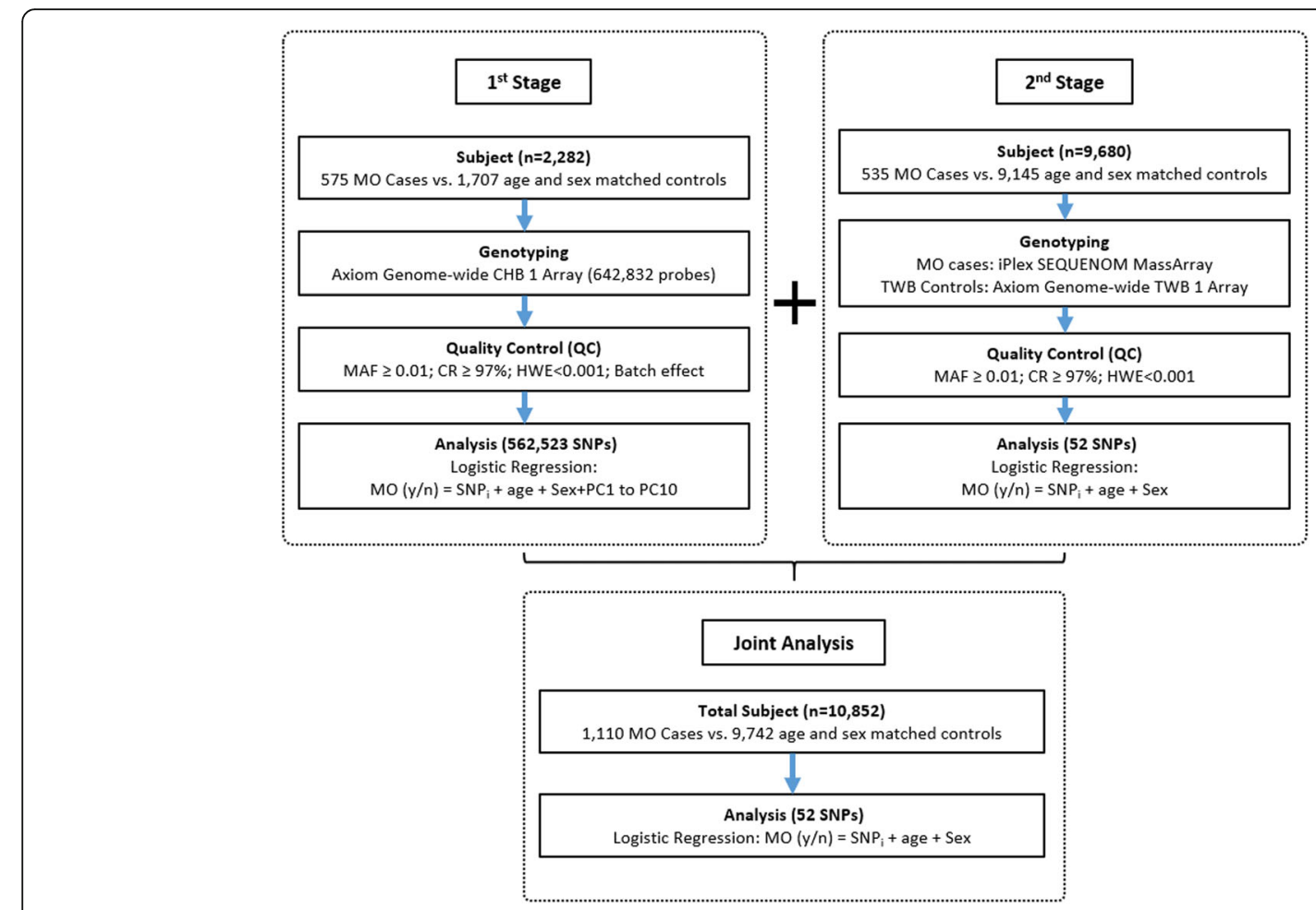

Fig. 2 The study flow chart of two-stage GWAS 
Genotyping was carried out by the National Center for Genome Medicine (NCGM) in IBMS, AS (http://ncgm. sinica.edu.tw/ncgm_02/index.html).

In the first-stage GWAS, Affymetrix Axiom ${ }^{\text {tw }}$ GenomeWide CHB 1 Array (Thermo Fisher Scientific Inc., US) was used as the genotyping platform for both $\mathrm{MO}$ cases and controls. The array had 640,674 markers. The quality of genotyping was evaluated by genotype calling rate (CR), minor allele frequency (MAF), and HardyWeinberg Equilibrium (HWE). SNPs that failed to pass the quality control $(\mathrm{CR}<97 \%, \mathrm{MAF}<5 \%$, or $\mathrm{HWE}<$ 0.001 ) were excluded. The remaining 562,523 SNPs were used in the first-stage GWAS.

In the second stage, the top SNPs selected from the first stage were validated using an independent sample set, as previously described (535 MO cases and 6242 controls). For MO subjects, the SNPs were genotyped using MassARRAY ${ }^{\circ}$ iPLEX Gold array from SEQUENOM MassARRAY ${ }^{\circ}$ System. For the TWB controls, SNPs were genotyped by Axiom ${ }^{\mathrm{m}}$ Genome-Wide TWB Array.

\section{Statistics}

To search for SNPs associated with MO, logistic regression (dichotomous MO status as outcome) analysis was performed at both stages, and joint analysis was conducted after sex and age adjustment. To adjust for population stratification and batch effects, principle components (PCs) from 1 to 10 derived from the principle component analysis (PCA) were included in the regression model. We adopted an ordinal genotype coding system (number of minor allele: 0, 1, and 2). Haploview software [76] was used to analyze linkage disequilibrium (LD) structure of the identified SNPs. Data were analyzed with PLINK and SAS 9.4 (SAS Inc., NC, USA).

\section{Supplementary information}

Supplementary information accompanies this paper at https://doi.org/10. 1186/s12863-019-0797-x.

Additional file 1: Table S1. Comparison of the basic characteristics of the $\mathrm{MO}$ and controls between the stage 1 and stage 2 . Table S2. The top 80 significantly associated SNPs in the first stage of the GWAS. Table S3. Replication study of the 85 loci associated with BMI in the Japanese population. Table S4. The association between the rs116917414 and BMI. Figure. S1. The LD plot of the FTO gene on Chr 16

\section{Abbreviations}

BMI: Body mass index; GWAS: Genome-wide association study; LD: Linkage disequilibrium; MAF: Minor allele frequency; MO: Morbid obesity; SNP: Single nucleotide polymorphism; TWB: Taiwan Biobank

\section{Acknowledgments}

We would like to thank all of the patients and other study participants who took part in this study. We also thank the National Center for Genome Medicine, Academia Sinica (Taipei, Taiwan) for performing genotyping of the subjects.

\section{Authors' contributions}

WHP and WJL conceived and coordinated the investigation. WJL and HCC were responsible for the specimen collection. HCC and KMC were responsible for the data analysis. KMC wrote the paper. WHP and WJL undertook revisions and $\mathrm{HCY}, \mathrm{CHC}$ and $\mathrm{HHC}$ contributed intellectually to the development of this paper. All authors have read and approved the manuscript.

\section{Funding}

This research received no specific grant from any funding agency in the public, commercial, or not-for-profit sectors.

\section{Availability of data and materials}

The data used in this study can be applied from Taiwan Biobank at https:// www.twbiobank.org.tw/new_web_en/index.php.

\section{Ethics approval and consent to participate}

This study has been approved by the Institutional Review Board of Academia Sinica. (approval number: AS-IRB01-15033). A signed informed consent has been obtained from every participant prior to the data collection in all the above studies.

\section{Consent for publication}

Not applicable.

\section{Competing interests}

The authors declare that they have no competing interests.

\section{Author details}

${ }^{1}$ Institute of Biomedical Sciences, Academia Sinica, Taipei City, Taiwan. ${ }^{2}$ Department of Gynecology and Obstetrics, School of Medicine, Taipei Medical University, Taipei City, Taiwan. ${ }^{3}$ Institute of Statistical Science, Academia Sinica, Taipei City, Taiwan. ${ }^{4}$ Department of Nutrition and Health Science, Chang Jung Christian University, Tainan City, Taiwan. ${ }^{5}$ Department of Surgery, Min-Sheng General Hospital, Taoyuan City, Taiwan. ${ }^{6}$ Institute of Population Health Sciences, National Health Research Institutes, Miaoli County, Taiwan.

Received: 12 March 2019 Accepted: 28 November 2019

Published online: 18 December 2019

\section{References}

1. Kitahara CM, Flint AJ, de Gonzalez a B, Bernstein L, Brotzman M, RJ MI, Moore SC, Robien K, Rosenberg PS, Singh PN, et al. Association between class III obesity (BMI of 40-59 kg/m2) and mortality: a pooled analysis of 20 prospective studies. PLoS Med. 2014:11(7):e1001673.

2. NCD-RisC. Trends in adult body-mass index in 200 countries from 1975 To 2014: a pooled analysis of 1698 population-based measurement studies with 19.2 million participants. Lancet. 2016;387(10026):1377-96.

3. Fryar CD, Carroll MD, Ogden CL. Prevalence of overweight, obesity, and extreme obesity among adults: United States, trends 1960-1962 through 2009-2010. National Center for Health Statistics: Hyattsville, MD; 2012.

4. Chang $\mathrm{HC}$, Yang $\mathrm{HC}$, Chang $\mathrm{HY}$, Yeh $\mathrm{CJ}$, Chen $\mathrm{HH}$, Huang $\mathrm{KC}$, Pan WH. Morbid obesity in Taiwan: prevalence, trends, associated social demographics, and lifestyle factors. PLoS One. 2017;12(2):e0169577.

5. Kasama K, Mui W, Lee WJ, et al. Obes Surg. 2012;22:677. https://doi.org/10 1007/s11695-012-0610-7.

6. Carroll W, Rhoades J. Obesity in America: Estimates for the U.S. Civilian Noninstitutionalized Population Age 20 and Older, 2009. Statistical Brief \#364. Rockville: Agency for Healthcare Research and Quality; 2012. http:// www.meps.ahrq.gov/mepsweb/data files/publications/st364/stat364.pdf.

7. Bray GA. Medical consequences of obesity. J Clin Endocrinol Metab. 2004; 89(6):2583-9.

8. Prospective Studies Collaboration, Whitlock G, Lewington S, Sherliker P, Clarke R, Emberson J, Halsey J, Qizilbash N, Collins R, Peto R. Body-mass index and cause-specific mortality in 900000 adults: collaborative analyses of 57 prospective studies. Lancet (London, England). 2009;373(9669):1083-96.

9. Pan WH, Yeh WT, Chen HJ, Chuang SY, Chang HY, Chen L, Wahlqvist ML. The U-shaped relationship between BMI and all-cause mortality contrasts with a progressive increase in medical expenditure: a prospective cohort study. Asia Pac J Clin Nutr. 2012;21(4):577-87. 
10. Colquitt JL, Pickett K, Loveman E, Frampton GK. Surgery for weight loss in adults. Cochrane Database Syst Rev. 2014;8:CD003641.

11. Abajobir AA, Abate KH, Abbafati C, Abbas KM, Abd-Allah F, Abdulkader RS, Abdulle AM, Abebo TA, Abera SF, Aboyans V, et al. Global, regional, and national incidence, prevalence, and years lived with disability for 328 diseases and injuries for 195 countries, 1990\&\#x2013;2016: a systematic analysis for the Global Burden of Disease Study. Lancet. 2016;390(10100): 1211-59.

12. Abajobir AA, Abate KH, Abbafati C, Abbas KM, Abd-Allah F, Abdulle AM, Abera SF, Aboyans V, Abu-Raddad LJ, Abu-Rmeileh NME, et al. Global, regional, and national comparative risk assessment of 84 behavioural, environmental and occupational, and metabolic risks or clusters of risks, 1990\&\#x2013;2016: a systematic analysis for the Global Burden of Disease Study. Lancet. 2016;390(10100):1345-422.

13. Abajobir AA, Abate KH, Abbafati C, Abbas KM, Abd-Allah F, Abera SF, Abraha HN, Abu-Raddad LJ, Abu-Rmeileh NME, Adedeji IA, et al. Global, regional, and national under-5 mortality, adult mortality, age-specific mortality, and life expectancy, 1970\&\#x2013;2016: a systematic analysis for the Global Burden of Disease Study. Lancet. 2016;390(10100):1084-150.

14. Abajobir AA, Abbafati C, Abbas KM, Abd-Allah F, Abera SF, Aboyans V, Adetokunboh O, Afshin A, Agrawal A, Ahmadi A, et al. Global, regional, and national age-sex specific mortality for 264 causes of death, 1980\&\#x2013; 2016: a systematic analysis for the Global Burden of Disease Study. Lancet. 2016;390(10100):1151-210.

15. Bouchard C. Gene-environment interactions in the etiology of obesity: defining the fundamentals. Obes (Silver Spring). 2008;16(Suppl 3):S5-S10

16. Ogden $C L$, Yanovski SZ, Carroll MD, Flegal KM. The epidemiology of obesity. Gastroenterol. 2007:132(6):2087-102.

17. van Vliet-Ostaptchouk JV, Snieder H, Lagou V. Gene-lifestyle interactions in obesity. Curr Nutr Rep. 2012;1:184-96.

18. Wardle J, Boniface D. Changes in the distributions of body mass index and waist circumference in English adults, 1993/1994 to 2002/2003. Int J Obes. 2008:32(3):527-32.

19. Bray MS, Loos RJ, McCaffery JM, Ling C, Franks PW, Weinstock GM, Snyder $M P$, Vassy JL, Agurs-Collins T, Conference Working G. NIH working group report-using genomic information to guide weight management: from universal to precision treatment. Obes (Silver Spring). 2016;24(1):14-22.

20. Elks CE, Hoed MD, Zhao JH, Sharp SJ, Wareham NJ, Loos RJ, Ong KK. Variability in the heritability of body mass index: a systematic review and meta-regression. Front Endocrinol (Lausanne). 2012;3:29.

21. Wardle J, Carnell S, Haworth CM, Plomin R. Evidence for a strong genetic influence on childhood adiposity despite the force of the obesogenic environment. Am J Clin Nutr. 2008:87(2):398-404.

22. Stryjecki C, Alyass A, Meyre D. Ethnic and population differences in the genetic predisposition to human obesity. Obes Rev. 2018;19(1):62-80.

23. Yang J, Bakshi A, Zhu Z, Hemani G, Vinkhuyzen AA, Lee SH, Robinson MR, Perry JR, Nolte IM, van Vliet-Ostaptchouk JV, et al. Genetic variance estimation with imputed variants finds negligible missing heritability for human height and body mass index. Nat Genet. 2015:47(10):1114-20.

24. Tam V, Turcotte M, Meyre D. Established and emerging strategies to crack the genetic code of obesity. Obes Rev. 2019;20(2):212-40.

25. Hebebrand J, Volckmar AL, Knoll N, Hinney A. Chipping away the 'missing heritability': GIANT steps forward in the molecular elucidation of obesity but still lots to go. Obes facts. 2010;3(5):294-303.

26. Xia Q, Grant SF. The genetics of human obesity. Ann N Y Acad Sci. 2013; 1281:178-90.

27. Hinney A, Nguyen $T$, Scherag A, Friedel S, Bronner G, Muller TD, Grallert H, Illig T, Wichmann HE, Rief W, et al. Genome wide association (GWA) study for early onset extreme obesity supports the role of fat mass and obesity associated gene (FTO) variants. PLoS One. 2007;2(12):e1361.

28. Meyre D, Delplanque J, Chevre JC, Lecoeur C, Lobbens S, Gallina S, Durand E, Vatin V, Degraeve F, Proenca C, et al. Genome-wide association study for early-onset and morbid adult obesity identifies three new risk loci in European populations. Nat Genet. 2009;41(2):157-9.

29. Scherag A, Dina C, Hinney A, Vatin V, Scherag S, Vogel Cl, Muller TD, Grallert H, Wichmann HE, Balkau B, et al. Two new loci for body-weight regulation identified in a joint analysis of genome-wide association studies for earlyonset extreme obesity in French and german study groups. PLoS Genet. 2010;6(4):e1000916.

30. Paternoster L, Evans DM, Nohr EA, Holst C, Gaborieau V, Brennan P, Gjesing AP, Grarup N, Witte DR, Jorgensen T, et al. Genome-wide population-based association study of extremely overweight young adults--the GOYA study. PLoS One. 2011:6(9):e24303.

31. Cotsapas C, Speliotes EK, Hatoum IJ, Greenawalt DM, Dobrin R, Lum PY, Suver C, Chudin E, Kemp D, Reitman M, et al. Common body mass indexassociated variants confer risk of extreme obesity. Hum Mol Genet. 2009; 18(18):3502-7.

32. Wang K, Li WD, Zhang CK, Wang Z, Glessner JT, Grant SF, Zhao H, Hakonarson $\mathrm{H}$, Price RA. A genome-wide association study on obesity and obesity-related traits. PLoS One. 2011;6(4):e18939.

33. Berndt Sl, Gustafsson S, Magi R, Ganna A, Wheeler E, Feitosa MF, Justice AE, Monda KL, Croteau-Chonka DC, Day FR, et al. Genome-wide meta-analysis identifies 11 new loci for anthropometric traits and provides insights into genetic architecture. Nat Genet. 2013;45(5):501-12.

34. Frayling TM, Timpson NJ, Weedon MN, Zeggini E, Freathy RM, Lindgren CM, Perry JR, Elliott KS, Lango H, Rayner NW, et al. A common variant in the FTO gene is associated with body mass index and predisposes to childhood and adult obesity. Sci. 2007;316(5826):889-94.

35. Scuteri A, Sanna S, Chen WM, Uda M, Albai G, Strait J, Najjar S, Nagaraja R, Orru M, Usala G, et al. Genome-wide association scan shows genetic variants in the FTO gene are associated with obesity-related traits. PLoS Genet. 2007:3(7):e115.

36. Wen W, Cho YS, Zheng W, Dorajoo R, Kato N, Qi L, Chen CH, Delahanty RJ, Okada Y, Tabara Y, et al. Meta-analysis identifies common variants associated with body mass index in east Asians. Nat Genet. 2012;44(3):307-11.

37. Magi R, Manning S, Yousseif A, Pucci A, Santini F, Karra E, Querci G, Pelosini C, McCarthy MI, Lindgren CM, et al. Contribution of 32 GWAS-identified common variants to severe obesity in European adults referred for bariatric surgery. PLoS One. 2013;8(8):e70735.

38. Hotta K, Nakata Y, Matsuo T, Kamohara S, Kotani K, Komatsu R, Itoh N, Mineo I, Wada J, Masuzaki H, et al. Variations in the FTO gene are associated with severe obesity in the Japanese. J Hum Genet. 2008;53(6):546-53.

39. Li H, Kilpelainen TO, Liu C, Zhu J, Liu Y, Hu C, Yang Z, Zhang W, Bao W, Cha $\mathrm{S}$, et al. Association of genetic variation in FTO with risk of obesity and type 2 diabetes with data from 96,551 east and south Asians. Diabetol. 2012; 55(4):981-95.

40. Liu Y, Liu Z, Song Y, Zhou D, Zhang D, Zhao T, Chen Z, Yu L, Yang Y, Feng $\mathrm{G}$, et al. Meta-analysis added power to identify variants in FTO associated with type 2 diabetes and obesity in the Asian population. Obes (Silver Spring). 2010;18(8):1619-24.

41. Cheung CY, Tso AW, Cheung BM, Xu A, Ong KL, Fong CH, Wat NM, Janus ED, Sham PC, Lam KS. Obesity susceptibility genetic variants identified from recent genome-wide association studies: implications in a chinese population. J Clin Endocrinol Metab. 2010;95(3):1395-403.

42. Chang YC, Liu PH, Lee WJ, Chang TJ, Jiang YD, Li HY, Kuo SS, Lee KC, Chuang LM. Common variation in the fat mass and obesity-associated (FTO) gene confers risk of obesity and modulates BMI in the Chinese population. Diab. 2008:57(8):2245-52.

43. Tan JT, Dorajoo R, Seielstad M, Sim XL, Ong RT, Chia KS, Wong TY, Saw SM, Chew SK, Aung T, et al. FTO variants are associated with obesity in the Chinese and Malay populations in Singapore. Diab. 2008;57(10):2851-7.

44. Wang L, Yu Q, Xiong Y, Liu L, Zhang X, Zhang Z, Wu J, Wang B. Variant rs1421085 in the FTO gene contribute childhood obesity in Chinese children aged 3-6 years. Obes Res Clin Pract. 2013;7(1):e14-22.

45. Speliotes EK, Willer CJ, Berndt SI, Monda KL, Thorleifsson G, Jackson AU, Lango Allen $\mathrm{H}$, Lindgren CM, Luan J, Magi R, et al. Association analyses of 249,796 individuals reveal 18 new loci associated with body mass index. Nat Genet. 2010:42(11):937-48.

46. Monda KL, Chen GK, Taylor KC, Palmer C, Edwards TL, Lange LA, Ng MC, Adeyemo AA, Allison MA, Bielak LF, et al. A meta-analysis identifies new loci associated with body mass index in individuals of African ancestry. Nat Genet. 2013;45(6):690-6.

47. Claussnitzer M, Dankel SN, Kim KH, Quon G, Meuleman W, Haugen C, Glunk V, Sousa IS, Beaudry JL, Puviindran V, et al. FTO obesity variant circuitry and adipocyte Browning in humans. N Engl J Med. 2015;373(10):895-907.

48. Mittal B, Srivastava A, Srivastava N. Is fat mass \& obesity-associated (FTO) gene master regulator of obesity ? Indian J Med Res. 2016;143(3):264-6.

49. Tung YCL, Yeo GSH, O'Rahilly S, Coll AP. Obesity and FTO: changing focus at a complex locus. Cell Metab. 2014;20(5):710-8.

50. Ma L, Hanson RL, Traurig MT, Muller YL, Kaur BP, Perez JM, Meyre D, Fu M, Korner A, Franks PW, et al. Evaluation of A2BP1 as an obesity gene. Diab. 2010;59(11):2837-45. 
51. Chowdhury NI, Tiwari AK, Souza RP, Zai CC, Shaikh SA, Chen S, Liu F, Lieberman JA, Meltzer HY, Malhotra AK, et al. Genetic association study between antipsychotic-induced weight gain and the melanocortin-4 receptor gene. Pharmacogenomics J. 2013;13(3):272-9.

52. Vaisse C, Clement K, Guy-Grand B, Froguel P. A frameshift mutation in human MC4R is associated with a dominant form of obesity. Nat Genet. 1998;20(2):113-4.

53. Fogel BL, Wexler E, Wahnich A, Friedrich T, Vijayendran C, Gao F, Parikshak N, Konopka G, Geschwind DH. RBFOX1 regulates both splicing and transcriptional networks in human neuronal development. Hum Mol Genet. 2012;21(19):4171-86

54. Shi J, Potash JB, Knowles JA, Weissman MM, Coryell W, Scheftner WA, Lawson WB, DePaulo JR Jr, Gejman PV, Sanders AR, et al. Genome-wide association study of recurrent early-onset major depressive disorder. Mol Psychiatry. 2011;16(2):193-201.

55. Wang C, Wang L, Ding Y, Lu X, Zhang G, Yang J, Zheng H, Wang H, Jiang $Y$, $\mathrm{Xu}$ L. LncRNA Structural Characteristics in Epigenetic Regulation. Int J Mol Sci. 2017;18(12).

56. Lopomo A, Burgio E, Migliore L. Epigenetics of obesity. Prog Mol Biol Transl Sci. 2016;140:151-84.

57. Thaker W. Genetic and epigenetic causes of obesity. Adolesc Med State Art Rev. 2017;28(2):379-405.

58. Heindel JJ, Blumberg B. Environmental Obesogens: mechanisms and controversies. Annu Rev Pharmacol Toxicol. 2019;59:89-106.

59. Shabana SSU, Irfan U. The gut microbiota and its potential role in obesity. Future Microbiol. 2018;13:589-603.

60. Smith NL, Felix JF, Morrison AC, Demissie S, Glazer NL, Loehr LR, Cupples LA, Dehghan A, Lumley T, Rosamond WD, et al. Association of genomewide variation with the risk of incident heart failure in adults of European and African ancestry: a prospective meta-analysis from the cohorts for heart and aging research in genomic epidemiology (CHARGE) consortium. Circ Cardiovasc Genet. 2010;3(3):256-66.

61. Della-Morte D, Beecham A, Rundek T, Wang L, McClendon MS, Slifer S, Blanton SH, Di Tullio MR, Sacco RL. A follow-up study for left ventricular mass on chromosome 12p11 identifies potential candidate genes. BMC Med Genet. 2011;12:100.

62. Henry FE, Sugino K, Tozer A, Branco T, Sternson SM. Cell type-specific transcriptomics of hypothalamic energy-sensing neuron responses to weight-loss. Elife. 2015;4.

63. Mizukami T, Kohno T, Hattori M. CUB and sushi multiple domains 3 regulates dendrite development. Neurosci Res. 2016;110:11-7.

64. Zeng F, Wang Y, Kloepfer LA, Wang S, Harris RC. ErbB4 deletion predisposes to development of metabolic syndrome in mice. Am J Physiol Endocrinol Metab. 2018;315(4):E583-93.

65. Benjamin AM, Suchindran S, Pearce K, Rowell J, Lien LF, Guyton JR, McCarthy JJ. Gene by sex interaction for measures of obesity in the Framingham heart study. J Obes. 2011;2011:329038.

66. Akiyama M, Okada Y, Kanai M, Takahashi A, Momozawa Y, Ikeda M, Iwata N, Ikegawa S, Hirata M, Matsuda K, et al. Genome-wide association study identifies 112 new loci for body mass index in the Japanese population. Nat Genet. 2017:49(10):1458-67.

67. Llewellyn C, Wardle J. Behavioral susceptibility to obesity: Geneenvironment interplay in the development of weight. Physiol Behav. 2015; 152(Pt B):494-501.

68. Sonestedt E, Gullberg B, Ericson U, Wirfalt E, Hedblad B, Orho-Melander M. Association between fat intake, physical activity and mortality depending on genetic variation in FTO. Int J Obes. 2011;35(8):1041-9.

69. Ahmad T, Lee IM, Pare G, Chasman DI, Rose L, Ridker PM, Mora S. Lifestyle interaction with fat mass and obesity-associated (FTO) genotype and risk of obesity in apparently healthy U.S. women. Diab Care. 2011;34(3):675-80.

70. Qi Q, Chu AY, Kang JH, Huang J, Rose LM, Jensen MK, Liang L, Curhan GC, Pasquale LR, Wiggs $J$, et al. Fried food consumption, genetic risk, and body mass index: gene-diet interaction analysis in three US cohort studies. BMJ. 2014;348:g1610.

71. Pan WH, Yeh WT. How to define obesity? Evidence-based multiple action points for public awareness, screening, and treatment: an extension of Asian-Pacific recommendations. Asia Pac J Clin Nutr. 2008;17(3):370-4.

72. Pan WH, Fann CS, Wu JY, Hung YT, Ho MS, Tai TH, Chen YJ, Liao CJ, Yang ML, Cheng AT, et al. Han Chinese cell and genome bank in Taiwan: purpose, design and ethical considerations. Hum Hered. 2006;61(1):27-30.
73. Chen $\mathrm{CH}$, Yang JH, Chiang CWK, Hsiung CN, Wu PE, Chang LC, Chu HW, Chang J, Song IW, Yang SL, et al. Population structure of Han Chinese in the modern Taiwanese population based on 10,000 participants in the Taiwan biobank project. Hum Mol Genet. 2016;25(24):5321-31.

74. Chen HH, Lee WJ, Fann CS, Bouchard C, Pan WH. Severe obesity is associated with novel single nucleotide polymorphisms of the ESR1 and PPARgamma locus in Han Chinese. Am J Clin Nutr. 2009;90(2):255-62.

75. Yang HC, Liang YJ, Wu YL, Chung CM, Chiang KM, Ho HY, Ting CT, Lin TH, Sheu SH, Tsai WC, et al. Genome-wide association study of young-onset hypertension in the Han Chinese population of Taiwan. PLoS One. 2009;4(5): e5459.

76. Barrett JC, Fry B, Maller J, Daly MJ. Haploview: analysis and visualization of LD and haplotype maps. Bioinformatics. 2005;21(2):263-5.

\section{Publisher's Note}

Springer Nature remains neutral with regard to jurisdictional claims in published maps and institutional affiliations.

Ready to submit your research? Choose BMC and benefit from:

- fast, convenient online submission

- thorough peer review by experienced researchers in your field

- rapid publication on acceptance

- support for research data, including large and complex data types

- gold Open Access which fosters wider collaboration and increased citations

- maximum visibility for your research: over $100 \mathrm{M}$ website views per year

At BMC, research is always in progress.

Learn more biomedcentral.com/submissions 